Illinois State University

ISU ReD: Research and eData

Theses and Dissertations

$4-5-2018$

\title{
The Relationship Between State Effectiveness And State Legitimacy: A Quantitative Test
}

Bich Thi Ngoc Tran

Illinois State University, bichtran.auw@gmail.com

Follow this and additional works at: https://ir.library.illinoisstate.edu/etd

Part of the Political Science Commons

\section{Recommended Citation}

Tran, Bich Thi Ngoc, "The Relationship Between State Effectiveness And State Legitimacy: A Quantitative Test" (2018). Theses and Dissertations. 893.

https://ir.library.illinoisstate.edu/etd/893

This Thesis is brought to you for free and open access by ISU ReD: Research and eData. It has been accepted for inclusion in Theses and Dissertations by an authorized administrator of ISU ReD: Research and eData. For more information, please contact ISUReD@ilstu.edu. 


\title{
THE RELATIONSHIP BETWEEN STATE EFFECTIVENESS AND STATE LEGITIMACY:
}

\section{A QUANTITATIVE TEST}

\author{
Bich Thi Ngoc Tran
}

\section{Pages}

Legitimacy is a contested concept in political science. The question of legitimacy has been addressed in various topics, including state formation, state building, and state failure. This research is an attempt to quantitatively test the relationship between state legitimacy and state effectiveness, specifically development in the economy, politics, and society. By examining the literature on legitimacy and its sources, the research tests the following hypothesis: a state with better performance in macro issues, including economic performance, social welfare, and political participation, is more likely to enjoy a higher level of legitimacy. In other words, this study attempts to establish a replicable formula for a state to improve and sustain its legitimacy.

KEYWORDS: state legitimacy; state performance; development 


\title{
THE RELATIONSHIP BETWEEN STATE EFFECTIVENESS AND STATE LEGITIMACY:
}

\author{
A QUANTITATIVE TEST
}

BICH THI NGOC TRAN

A Thesis Submitted in Partial Fulfillment of the Requirements for the Degree of

MASTER OF ARTS

Department of Politics and Government

\section{ILLINOIS STATE UNIVERSITY}


(C) 2018 Bich Thi Ngoc Tran 


\section{THE RELATIONSHIP BETWEEN STATE EFFECTIVENESS AND STATE LEGITIMACY:}

\section{A QUANTITATIVE TEST}

\section{BICH THI NGOC TRAN}

COMMITTEE MEMBERS:

Ali Riaz, Chair

T.Y. Wang

Nancy S. Lind 


\section{ACKNOWLEDGMENTS}

For support with the ideas and completion of this thesis, I am grateful to my committee members: Dr. Ali Riaz, Dr. Nancy S. Lind, and Dr. T.Y. Wang of the Department of Politics and Government at Illinois State University for their guidance and patience through the process of forming the idea, changing topic at the last minute due to my personal circumstance, and developing the new thesis which is completed and presented now. I am thankful to Dr. Ali Riaz for introducing the concept of 'state legitimacy' and helping me to establish the cornerstones of the thesis. I thank Dr. T.Y. Wang for patiently helping me with the quantitative part and logic of the presentation. I thank Dr. Nancy S. Lind for her constructive comments on several drafts and constant pushing so that I could finish the final draft on time. I also thank Dr. L.J. Zigerell who also provided timely assistance during the course of this thesis. Special thanks to Cherie Valentine and Mary Taylor from the Department of Politics and Government for providing me with support and shelter in their office/working area whenever I needed. I thank my fellow graduate students in the department, my friends, my roommates, and my puppy buddies for their understanding and support during the time of writing this thesis. Last but not least, it is my family, my parents and my brothers who constantly encouraged me to pursue my education to make this thesis possible. It has been truly a memorable journey completing this work. 


\section{CONTENTS}

$\begin{array}{lll}\text { Page } & \end{array}$

ACKNOWLEDGMENTS

CONTENTS

TABLES

FIGURES $\quad$ v

CHAPTER I: INTRODUCTION 1

CHAPTER II: LITERATURE REVIEW

Defining State Legitimacy $\quad 5$

$\begin{array}{ll}\text { Sources of Legitimacy } & 6\end{array}$

The Role of State Legitimacy in the Social Contract $\quad 8$

Characteristics of State Legitimacy $\quad 9$

$\begin{array}{ll}\text { Defining State Performance } & 9\end{array}$

$\begin{array}{ll}\text { Measuring State Legitimacy } & 10\end{array}$

CHAPTER III: THEORETICAL FRAMEWORK AND HYPOTHESES 11

$\begin{array}{ll}\text { Social Contract Theory } & 11\end{array}$

Habermas' D-Principle 13

Note on Cultural and Historical Context of State Legitimacy 14

Conceptualizing Theory and the Hypothesis 16

$\begin{array}{ll}\text { CHAPTER IV: RESEARCH DESIGN } & 18\end{array}$

$\begin{array}{ll}\text { Variable Description } & 18\end{array}$

$\begin{array}{ll}\text { Statistical Analysis } & 22\end{array}$

CHAPTER V: ANALYSIS 24 
CHAPTER VI: POLICY RECOMMENDATIONS, CONTRIBUTION AND FUTURE

$\begin{array}{ll}\text { RESEARCH } & 27\end{array}$

$\begin{array}{ll}\text { Policy Recommendations } & 27\end{array}$

$\begin{array}{ll}\text { Contribution and Future Research } & 28\end{array}$

$\begin{array}{ll}\text { CHAPTER VII: LIMITATIONS } & 31\end{array}$

REFERENCES $\quad 32$

APPENDIX: DESCRIPTION OF VARIABLES IN PRIMARY DATASET 39 


\section{TABLES}

Table Page

1. Summary of Tables 22

2. Mixed Effects Model of State Legitimacy on Democracy, Social Welfare and Economic Development 2005-2017 


\section{FIGURES}

Figure $\quad$ Page

1. Research Design 17 


\section{CHAPTER I: INTRODUCTION}

All states claim to be legitimate, even those which are wrecked by civil war, confronting secessionist moments, or facing debilitating insurgencies. States which are miserably failing to provide common goods to its citizens or have become safe havens of transnational terrorist groups have no fewer claims on legitimacy. Insisting that its existence is inevitable and unquestionable and that its monopoly on violence is proof of its legitimacy, state attempts to dismiss and denounce any internal threats and external interventions are contrary to its claim. The claim is louder, often raucous, when the state has lost control over a territory and population, or worse yet, it is intervened by external forces. However, these claims are not always true. Which states are legitimate? How can we measure legitimacy? What makes a state more legitimate? Is there a way to quantitatively examine elements that contribute to state legitimacy? This thesis intends to answer these questions. My objective is to empirically examine the relationship between state effectiveness and state legitimacy based on a set of variables applicable to a diverse group of countries, and consequently make recommendations as to how states can boost their legitimacy.

Legitimacy is a contested concept in political science. The question of legitimacy has been addressed in various topics, including state formation, state building, and state failure. The Organization for Economic Cooperation and Development (OECD 2010) has described legitimacy as the extent to which people recognize the existence of a state and see it as the ultimate authority to which no other force can be superior. In the context of state formation, legitimacy is the means and end of every state entity to create and maintain its existence. In the conversation of state building, legitimacy concerns how a state retains and consolidates its legal status. In state failure, the discourse of legitimacy involves arguments of how a state loses its 
rightful authority and ways to retrieve it. Given the various dimensions, legitimacy has not only remained an elusive and normative concept but also conceptualizing and measuring its degree and effect has been a daunting task.

State legitimacy is different from regime legitimacy and government legitimacy. State is comprised of population, territory, government, and sovereignty, usually divided into two components: physical bases and political bases. State is defined as "the complex of institutions that constitute the organization of political authority" (Larson 1980: 19). Regime, on the other hand, is a "permanent structure of domination and coordination including a coercive apparatus and the means to administer a society and extract resources from it" (Fishman 1990: 428). Regime, thus, relates to political power and its relations with 'the broader society' in the contexts of both 'formal and informal institutions' (Fishman 1990: 428) which perpetuate "the values embodied in the principles and norms and implies that rules and procedures, derive from, and are secondary to, these norms" (Lawson 1991: 4). Government also comprises of institutions but is an instrument to govern by the regime and to a larger extent to form a state. Government, in another word, is "the agency through which the state acts in the political community" (Larson 1980: 19). People may disagree with the government or disapprove of the incumbent regime, but that does not translate into rejecting the idea of a unified and cohesive state. For example, political opponents of a ruling party/elite may not accept the right of the incumbent government or regime to rule but they are neither opposed to the existence of the state nor do they intend to establish a new state. In a hierarchical order, state is the most sustainable entity compared to regime and government. Government is the most vulnerable entity among all.

In this study, legitimacy is considered in the context of state building. Discussions will center on the relationship between state legitimacy and state performance and how a state can 
retrieve and sustain legitimacy through its performance. This research, thus, is an attempt to quantitatively test the relationship between state legitimacy and state effectiveness and development in the economy, politics, and society. By examining the literature on legitimacy and its sources, the research tests the following hypothesis: a state with better performance in macro issues, including economic performance, social welfare, and political participation, is more likely to enjoy a higher level of legitimacy. In other words, this study attempts to establish a replicable formula for a state to improve and sustain its legitimacy. 


\section{CHAPTER II: LITERATURE REVIEW}

The literature on state legitimacy tends to cover three aspects: the origin of state legitimacy, the role of legitimacy in state-building, and the measurement of state legitimacy. The focus of the extant literature on measuring state legitimacy is limited to two aspects of the concept: the normative measurement and performance-based measurement. Max Weber (1947), David Easton (1965), and Jürgen Habermas (1996, 1993) have discussed the normative analysis at length. In their writings, state legitimacy is originated in a philosophical framework, where elements of culture and social relationship (Weber 1947), trust (Easton 1965), and discourse (Habermas 1993, 1993) are woven into a normative moral, social, and political constructivist proxy framework. This proxy framework focuses on individual reasoning, moral principles, cultural legacies and the intrinsic values of legitimacy. However, in this framework, state legitimacy is theoretically defined without quantitative empirical studies. Thus, state legitimacy appears a more intangible and self-perpetuating process.

While many have argued that state legitimacy comes from the state's provision of goods and services as a result of its social contract with citizens, very few quantitative studies have been conducted to examine this claim. Bruce Gilley’s studies in 2006 and 2009 are the exceptions. Gilley's studies aim at explaining the complexity of political legitimacy by providing "a common meaning of political legitimacy and replicable way to measure it" (2006: 500). Gilley includes 72 countries in his studies and concludes that "good governance, democratic rights, and welfare gains provide the most reasonable and robust determinants of legitimacy" (2006: 47-8). Gilley uses a dichotomous orientation: constitutive or substitutive, and attitude or behavior, and three sub-types of legitimacy: view of legality, view of justification, and the act of consent, to measure political legitimacy. 


\section{Defining State Legitimacy}

State legitimacy is one of the critical concepts in studying state building. Max Weber discusses legitimacy as obedience to the authority bounded in the idea of "social relationships and cultural phenomena by authority and imperative co-ordination" (1947: 324-328). David Easton's (1965) classic study A Framework for Political Analysis argues that the legitimacy of democratic political systems depends on how much citizens trust and support their government. Easton's definition is normative and subjective, thus, to a certain extent, it serves as a larger umbrella to discuss state legitimacy from the population. Mcloughlin defines state legitimacy as the people's acceptance of "the state's fundamental right to rule over them" (2014: 2). The state, thus according to Mcloughlin, has the power to rule without facing resistance. However, this definition does not clarify the monopolistic trait of the state. The word 'fundamental' indicates power as the first privilege yet does not explicitly refer to the monopoly of violence. Gilley defines state legitimacy in a moral perspective from the subjects' point of view when he indicates that "a state is more legitimate that is treated by its citizen as rightfully holding and exercising political power" (2006: 500).

In sum, from the above definitions, state legitimacy centers on power, acceptance, rightfulness, and obedience. This study adopts the description provided by the OECD (2010) that defines state legitimacy as "the extent that people regard the state as satisfactory and believe that no available alternative would be vastly superior." There are two advantages to adopting this definition. First, the definition indicates the 'satisfactory' element of the population towards the state's performance. Second, it indicates the level of trust for the state among the people. In the 
following parts, the study will dig deeper into sources of state legitimacy and identify the determinant factors of state legitimacy

\section{Sources of Legitimacy}

Max Weber (1947) suggests that there are three sources of state legitimacy: tradition, charisma, and legal-rational authority. Traditional legitimacy arises from the faith that people have in a particular political authority because it has been there for a long time. This type of legitimacy can be found in the monarchic system and tribal societies. Charismatic legitimacy is personal when state legitimacy relies on a political figure or their rulers. The people are attached to the person by his/her personality traits and ideology. Revolutionary leaders often create a charismatic legitimacy to gain and consolidate their power. The last source of legitimacy that Weber suggests is a legal-rational authority. By legal-rational authority, Weber means the rationality of the rule of law of the state. This last source of legitimacy indicates a social contract among rational actors. It faces the same limitation as assuming that all political actors are rational. While Weber explains various kinds of legitimacy, he has not offered a way to measure legitimacy.

Gippert defines legitimacy as "a social phenomenon that depends on the individual or collective interaction between the rule-giver and the rule-recipient" (2016: 524). He distinguishes between two dimensions for creating legitimacy: process legitimation which means how a state becomes legitimate, and perceptions of legitimacy. Within the two dimensions, two types of legitimacy emerge: procedural legitimacy and output-oriented legitimacy. Procedural legitimacy is to "arise when the exercise of authority matches the individual's normative benchmarks about how such an exercise should work" (2016: 524). This source can be risky to the state's security 
with regard to majority dominance and elite corruption. The "individual's normative benchmarks" about how government should work may be an illusion of indoctrinated propaganda or clientelism. The state may try to please one group while violating fundamental rights of another group. The second type of legitimacy is output-oriented legitimacy. Gippert suggests that "output-oriented legitimacy arises from the ends of which a system works" (2016: 526-7). We can see this type of legitimacy in emerging economies or newly industrialized states including South Korea, Singapore, Taiwan, China, and Vietnam.

Wesley argues that state legitimacy is seen as "flowing ultimate(ly) from the state's effectiveness" (2008: 379). This approach is shared by some scholars who address sources of legitimacy. Nevertheless, legitimizing the state by its 'effectiveness' indicates a rational approach to state building. By calculating the effectiveness of the state, the population has a right to evaluate the regime and bestow the regime with legitimacy.

Habermas $(1993,1996)$ ties political legitimacy to morality and democracy where he emphasizes the concept of 'discourse principle' which can be understood as "a rule of action or choice is justified, and thus valid, only if all those affected by the rule or choice could accept it in a reasonable discourse” (Bohman and Rehg 2007). In Habermas' argument, state legitimacy neither exists in a vacuum nor works as a self-entitled political power. It is a result of reasonable political discourse with universal acceptance among its stakeholders, including both the state itself and its people. Thus, according to Habermas, democracy ties closely to state legitimacy because it allows everyone to participate in all political discourse.

The OECD report about state legitimacy and state fragility provides a summary of the discussion in sources of state legitimacy. The 2010 report identifies four primary sources of legitimacy (2010: 23): (a) Input or process legitimacy, (b) Output or performance legitimacy, (c) 
Shared beliefs, and (d) International legitimacy. This study examines the theory of legitimacy based on performance, particularly, the holistic development of a state. The performance theory is different from the others because it allows researchers to test the relationship empirically. With the definition and sources of state legitimacy identified, it is equally important to understand why legitimacy is crucial to state building and a state's survival.

\section{The Role of State Legitimacy in the Social Contract}

Hobbes, Locke, and Rousseau argue that the state exists as part of a 'social contract' between the people and the state where the state is granted a monopoly on violence. The wild and hostile state of nature provides for the rise of a state and sovereign. In particular, Hobbes' Leviathan depicts a masculine, powerful sovereign, but also brings a sense of protection from the sovereign to the people. Locke's perception of the state is associated with the concept of private property. Relatedly, the state plays a crucial role in providing security (the military and army) and resolving property conflicts (the judicial system). Obtaining legitimacy is the political apparatus that enables the state to exercise its monopoly on violence. Rousseau, on the other hand, emphasizes the notion of 'compact contract' which shares the same definition with the 'social contract.'

Gilley suggests that "political legitimacy is a major determinant of both the structure and operation of the states" (2006: 499). Without having legitimacy, the state cannot acquire the population's support. Frickel and Davison further argue that "the central position of legitimacy" is to maintain the nation-state's highest position (2004: 6). Declining legitimacy is considered a signal of internal instability and domestic violence. As a state is failing, it leads to further regional instability which is a significant threat to neighboring states. On a larger scale, it may 
lead to humanitarian crises, influencing global political affairs. Cleassen contends that "legitimacy is the most important form of support for a ruler, securing the agreement and cooperation of the ruled" (1988: 42). Legitimacy, thus, influences the survival of a state, which results in the ultimate power of the people in sustaining the state.

\section{Characteristics of State Legitimacy}

Legitimacy is ever-changing and fundamentally different from one state to another depending on their social, political, and economic situations (Claessen 1988: 43; Weber 1947: 325). Transitions from one form of society to another indicate changes in social structures and the relationship between the ruler and the ruled. This also refers to changes in the perception of legitimacy. In the contemporary era, state legitimacy can rest on democratic institutions, state history, and state capacity.

Additionally, state legitimacy is a process. And it is indeed a long one. Moore discusses the process of legitimation of government and party in Tanzania and argues that "the legitimacy of the state is consciously tied to a philosophical position that its leader knows it cannot fully act on" (1988:156). The gap is between the traditional African belief in egalitarianism and increasing pressure from the state's inability to deliver democracy and equality to all its citizens. The post-colonial period and the government's adoption of relevant changes allow the country to be one of the most stable in Africa (1988: 171).

\section{Defining State Performance}

This study examines the hypothesized positive relationship between state performance and legitimacy. State performance indicates the following: economic development, public 
welfare, and democratic development. These factors are chosen for they are performed or administered by the state. National security regarding military forces and capacity in political violence and insurgency are overlooked in this study for two reasons. First, the study only concerns domestic politics and the state's outputs. Second, in designing the research, substitute variables will be used to close the gap between national security and stability.

\section{Measuring State Legitimacy}

As noted earlier, legitimacy is often discussed theoretically. One of the rare quantitative research studies is done by Bruce Gilley $(2006,2012)$ who conducted "a quantitative measurement of the political legitimacy of states in the late 1990s and early 2000s ..." Gilley measured legitimacy "using a constitutive (cause) or substitutive (effect) approach" (2006: 505). The state legitimacy factors are the views of legality, views of justification, and acts of consent. Gilley examined 72 states in 2006. In 2012, he updated 52 countries of the previously explored 72 countries. Based on different indicators of legality, justification, and consent, Gilley devised a ranking system for state legitimacy. Gilley stated that his "legitimacy measurement is composed half of the attitudinal indicators and half of the behavioral indicators, distinguishing it from purely attitudinal measures" (2012: 695). This study is inspired by Gilley's research and aims to answer how to test the relationship between state legitimacy and its performance in social, political and economic indicators. 


\section{CHAPTER III: THEORETICAL FRAMEWORK AND HYPOTHESES \\ Social Contract Theory}

This study adopts the rational actor approach, believing that political actors would always make decisions to maximize their interests. The first theory taken is 'social contract theory' where the state comes into being in a rational, voluntary and mutually beneficial agreement between the state and the people. Rousseau famously said, "Man is born free; and everywhere he is in chains" (1950: 3 ). The chains that he mentioned are 'sacred' social orders resulting from a 'social compact' which Rousseau defined as the foundation of the existence of the state. The law of nature, according to Rousseau, focuses on the premise that humans are 'the chief instruments' of their 'self-preservation', and that the solution to avoid perishing because of 'that primitive condition' is to "find a form of association which will defend and protect with the whole common force the person and goods of each associate, and in which each, while uniting himself with all, may still obey himself alone, and remain as free as before" (1950: 13-14). Rousseau's maxim sets a cornerstone for the existence of the state. Rousseau continues that this bounded sovereignty means the production of a 'civil state' (1950: 18), and this civil state enables man to acquire 'moral liberty' which "makes him truly a master of himself" (1950: 19).

In the 'state of nature' discourse, Thomas Hobbes contends that men by nature are equal, the natural condition of humanity is misery and full of warfare. He writes, "if any two men desire the same thing, which nevertheless they cannot both enjoy, they become enemies; and in the way to their End (which is principally their own conservation, and sometimes their delectation only,) endeavor to destroy, or subdue one another" (1952: 95). Hobbes' fundamental law of nature states, "that every man, ought to endeavor Peace, as far as he has a hope of obtaining it; and when he cannot obtain it, that he may seek, and use, all helps, and advantages of warfare" (1952: 
100). Therefore, to void warfare and the hostile environment of the state of nature, people ought to participate in a social contract which Hobbes describes as a "mutual transferring of right" (1952: 102).

One of the Contractors, may deliver the Thing contracted for on his part and left the other to perform his part at some determinate time after, and in the meantime be trusted; and then the Contract on his part, is called Pact, or Covenant: Or both parts may contract now, to perform hereafter: in which cases, he that is to perform in time to come, be trusted his performance is called Keeping of Promise, or Faith; and the failing of performance (if it be voluntary) Violation of Faith (1952:102).

Elements of discourse, mutual trust, and democracy are well presented in the above description of a social contract. There ought to be discourse between the contractors to form an agreement and build mutual trust based on a democratic transferring of rights where men are born equal and have the right to self-protection in the hostile state of nature. This rationale sets forward the formation of the state as an entity to preserve and protect its people in exchange for the people's rights and obligations. Even though in Leviathan, Hobbes's central argument is the establishment of a sovereign figure or in other words a monarch to protect the people, one need not necessarily agree yet still may contend with the reasoning of having a sovereign power to organize the country.

On the idea of sovereignty, John Locke contends, "such a power can never be established unless each and every individual surrenders the whole of this natural liberty of his, however great it may be, to a legislator, granting it to him who with the authority of all (by proxy, as it was), empowered by the general consent of each, makes valid laws for them" (1967: 231). To a certain extent that Locke's discourse of God is not enclosed in this argument of sovereignty, his idea of exchanging and mutual benefit still works for the 'social contract' maxim. 
The theory used in this research particularly focuses on measuring state legitimacy through a population's satisfaction with state services, assuming that state performance would enhance the population's satisfaction of the state and, as a result, enhance state legitimacy. Thus, the study employs performance as a source of state legitimacy by embracing social contract theory. The approach demonstrates the ability of the state to perform and resolve public issues, for example, security, education, and economic development. It, therefore, is expected that as the state continues to deliver goods and services, it will retain inherent legitimacy.

\section{Habermas' D-Principle}

The second adopted theory is Habermas' 'discourse principle' where political legitimacy is tied to democratic institutions. Habermas develops his theory of communicative action substantially informed by Kant and Aristotle in moral reasoning and ethics. The notion of law and legality by Habermas is closely associated with democratic institutions achieved in mutual discourse. The D principle states: Just those action norms are valid to which all possibly affected persons could agree as participants in rational discourse (1996: 107).

He argues that laws "draw their legitimacy from a procedure based for its part on the principle of popular sovereignty. The paradoxical emergence of legitimacy out of legality must be explained using the rights that secure for citizens the exercise of their political autonomy" (1996: 83). The discourse principle is based on moral norms and their 'universalization principle' (1996:109) where morality is conceived as "an authority that crosses the boundaries between private and public spheres" (1996: 109).

Habermas' discourse principle ties closely with social contract theories as he acknowledges that basic rights "should be introduced first of all from the perspective of a 
nonparticipant" (1996: 118) in democratic platforms to transcend the intrinsic value of legitimacy from a democratic and unbiased point of view. He summarizes that "the key idea is that the principle of democracy derives from the interpretation of the discourse principle and the legal form" (1996: 121) for what he calls a logical genesis of rights. Communicative action, thus, is the means to exchange ideas and make a decision by participating and expressing one's self. The democratic platform which allows free and voluntary participation will facilitate the discourse in achieving collective consensus.

In Habermas' argument, neither does state legitimacy exist in a vacuum nor does it work as a self-entitled political power. It is a result of reasonable political discourse with common acceptance among its stakeholders, including both the state itself and its people. The 'discourse principle' set the foundation for the primary dependent variable in this collected dataset which ties together the rule of law, institutionalized democracy, property right, political rights and civil liberty in measuring state legitimacy.

\section{Note on Cultural and Historical Context of State Legitimacy}

Colonialization and cultural diversity have been considered by many as determining factors of state legitimacy. Constructivism argues that colonialization plays an essential role in defining structures and values in post-colonial countries. Ekeh (1980) argues that there are three types of social structures in the colonies, namely transformed social structures, migrated social structures and emergent social structures that are shaped by colonialism:

- Transformed social structures: the transformations of pre-colonial indigenous institutions, which, in their transformed states, operate within the new meanings 
and symbols of colonialism and in a widened new socio-cultural system and framework (Ekeh 1980: 9).

- Migrated social structures and constructs: transfer of values of the imperial West to Asia and Africa and engrafted onto the new colonial situation to include democracy and the rule of law with their peculiar Western connotations; such institutions as universities and national statehood; such establishments as bureaucracy and elected parliaments: these and many more were imported models to the colonial situation, and they form the core of the resultant migrated social structures. (Ekeh 1980: 10).

- Emergent social structures: these were not indigenous to Africa, and they were not brought from the outside. They were generated, born, from the space-and-time span of colonialism. (Ekeh 1980: 10)

Noting that democracy is an essential component in my theory, it is crucial to this study to acknowledge the role of colonial legacies on development and democracy's survival. Indeed, a significant amount of research has demonstrated the relationship between the history of colonialization, the period of colonialization and economic as well as democratic political development in post-colonial states, specifically African states (Bernhard, Reenock \& Nordstrom 2004; Grier 1999; Blanton, David \& Athow 2001). For example, Bernhard, Reenock, and Nordstrom found that the "colonial past generally diminishes a democracy's prospects for survival" (2004: 245). They also found that the "legacy of colonialism seems to be a product of underdevelopment and high of social fragmentation, and the relationship between the state and civil society" (Bernhard et al.: 245). Grier found that "the identity of the colonizing power has a significant and permanent effect on subsequent growth and development" and that "colonies that 
were held for longer periods of time than other countries tend to perform better, on average, after independence" (Grier 1999: 329). Blanton, David, and Athow (2001: 473) also contend that "European colonialism had profound, lasting, and wide-ranging effects on the development of contemporary African states. One of the most profound legacies of the colonial period has been ethnic conflict".

Culture, similarly, is a debated element of state legitimacy. From the argument of Asian values, it is critical to examine the role of historical, linguistic, ethnic, and religious diversity's role in shaping state legitimacy. In this study, the unit of analysis is the state. Featuring cultural variables also serves to distinguish the countries in the dataset. Therefore, it is crucial to this study to include the history of colonialization and cultural diversity in examining the relationship between state legitimacy and development.

\section{Conceptualizing Theory and the Hypothesis}

Drawing on Social Contract theory and Principle-D theory, and building on the rational actor approach, this study argues that democratic participation through political discourse satisfies citizens' needs for unconditioned morality in participating in politics to preserve their basic rights and benefits. Democratic practices, thus, have their intrinsic values that enhance one's welfare. Each contributes inputs into the decision-making process and democracy and consolidation of democracy constitutes a critical role in state legitimacy. However, one may raise some 'exceptions' to this theory as state-legitimacy based on democratic participation is being challenged by models of countries including Asian countries such as China, Singapore, and Vietnam, or Middle East countries or Caribbean Cuba. This theory holds that democratic discourse between the government, regardless of direct or representative democracy, will 
improve state legitimacy. A study on the relationship between democracy and state legitimacy, thus, is needed to challenge the existence of these authoritarian states and support the democratic foundation of state legitimacy. It is against this backdrop that this study argues that the relationship between citizens and states is strengthened by mutual discourse, using Habermas' theory.

The hypothesis tested is: a state with better performance in macro issues, including economic performance, social welfare, and political participation, is more likely to enjoy a higher level of legitimacy. Through testing this hypothesis, the study aims at offering a replicable formula for existing and developing states to achieve and sustain political legitimacy.

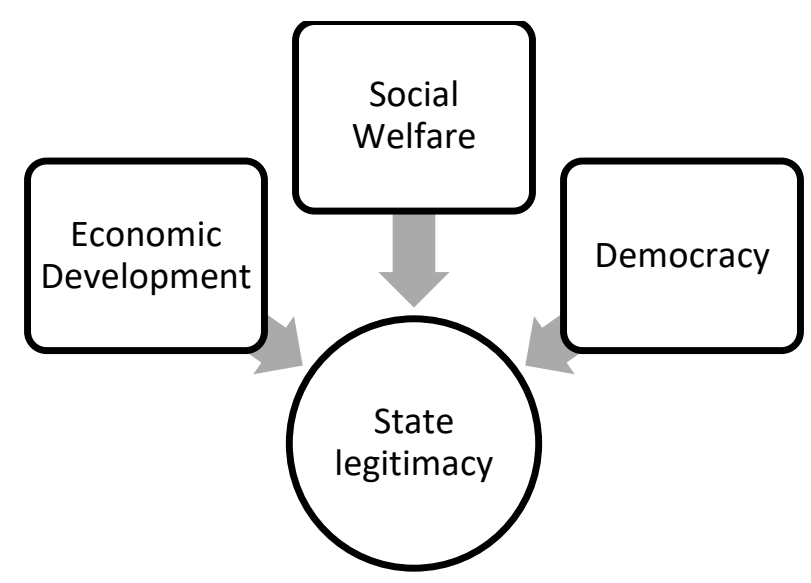

Figure 1. Research Design 


\section{CHAPTER IV: RESEARCH DESIGN}

The study uses data from the dataset compiled by Jan Teorell, Stefan Dahlberg, Sören Holmberg, Bo Rothstein, Anna Khomenko, and Richard Svensson at the University of Gothenburg, Sweden. Data are collected from 159 countries between 2005 and 2017. Because the unit of analysis is country-year, a pooled cross-sectional and time-series research design is adopted $^{1}$.

\section{Variable Description}

The primary dependent variable is State Legitimacy. State Legitimacy indicates corruption and lack of representativeness in the government. It includes pressures and measures related to corruption, government effectiveness, political participation, electoral processes, levels of democracy, illicit economy, drug trade, protests and demonstrations, and power struggles (Teorell et al. 2013: 283). The variable of State Legitimacy is on a scale from 0 to 1 with 0 representing the lowest legitimacy and 1 representing the highest legitimacy ${ }^{2}$.

There are ten independent variables included in this study: GDP Growth Rate (\%), Unemployment Rate (\%), Public Service, Institutionalized Democracy, Political Rights, Property Rights, Civil Liberties, Ethnic Fractionalization, Religion Fractionalization, and Colonial Origin.

\footnotetext{
${ }^{1}$ The study uses data from the dataset initially compiled by Jan Teorell, Stefan Dahlberg, Sören Holmberg, Bo Rothstein, Anna Khomenko, and Richard Svensson at the University of Gothenburg, Sweden. It consists of approximately 2500 variables from more than 100 data sources. In the Quality of Government Standard Cross-sector dataset, data from and around 2013 are included. Data from 2013 are prioritized; however, if no data are available for a country for 2013, data from 2014 are included. If no data exist for 2014, data from 2012 are included, and so on up to a maximum of $+/$ - three years. The unit of analysis is country (Teorall et al. 2013: 5). The dataset has been modified in this study and all variables are recoded to the scale 0 (lowest/worst) to 1 (highest/best).

https://qog.pol.gu.se/data/datadownloads/qogstandarddata

${ }^{2}$ See Appendix for full description of the variable.
} 
The first element of the research concerns democracy and state legitimacy. The Dprinciple supports a positive relationship between level of democracy and state legitimacy. As people are involved in democratic discourse in politics in democratic institutions, the level of state legitimacy is expected to rise as the sense of ownership and engagement facilitates their acceptance towards the state. I, thus, include Institutionalized Democracy, Property Rights, Political Rights, and Civil Liberty as independent variables.

Institutionalized Democracy is derived from coding the competitiveness of political participation, the openness and competitiveness of executive recruitment, and constraints on the chief executive with 0 meaning the lowest level of operational democracy and 1 meaning the highest level of operational democracy ${ }^{3}$.

Political Rights measures how people participate freely in the political process, including the right to vote freely for distinct alternatives in legitimate elections, compete for public office, join political parties and organizations, and elect representatives who have a decisive impact on public policies and are accountable to the electorate. The specific list of rights considered varies over the years. Countries are ranked between 0 (most free) to 1 (least free) $)^{4}$.

Property Rights scores the degree to which a country's laws protect private property rights and the degree to which its government enforces those laws. It also accounts for the possibility that private property will be expropriated. Additionally, it analyzes the independence of the judiciary, the existence of corruption within the judiciary, and the ability of individuals and businesses to enforce contracts. The country's property rights score ranges from 0 to 1 , where 1 represents the maximum degree of protection of property rights ${ }^{5}$.

\footnotetext{
${ }^{3}$ See Appendix for full description of Institutionalized Democracy.

${ }^{4}$ See Appendix for full description of Political Rights.

${ }^{5}$ See Appendix for full description of Property Rights.
} 
Civil Liberty measures the freedoms of expression and belief, associational and organizational rights, the rule of law, and personal autonomy without interference from the state. The more specific list of rights considered varies over the years. Countries are ranked between 0 (most free) and 1 (least free $)^{6}$.

The research also tests the positive relation between economic development and state legitimacy. GDP Growth Rates and Unemployment Rates in this model are two of the primary indicators of economic development. Even though the two variables are closely related (Okun 1962), they reflect two different aspects of the economy. Economic growth rate reflects the volume and size of the economy while unemployment rate reflects how many people are unemployed not counting the people who are actively searching for jobs. People move in and out the labor force which may be independent of the size and volume of the economy as the economy twists and adapts itself to changing circumstances. GDP growth rate is the percentage that the economy has grown in a given time within a country's boundary. Unemployment Rate (\%): Unemployment refers to the share of the labor force that is without work but available for and seeking employment ( $\%$ total labor force) ${ }^{7}$

The third element concerns the relationship between social welfare and state legitimacy. In this model, Public Service provides indicators of the quality of goods and services provided by the state in the 'Social Contract'. Public Service measures the provision of health, education, and sanitation services, among others, as critical roles of the state, includes pressures and measures related to policing, criminality, education provision, literacy, water and sanitation, infrastructure,

\footnotetext{
${ }^{6}$ See Appendix for full description of Civil Liberties.

${ }^{7}$ See Appendix for full descriptions of GDP Growth Rates and Unemployment Rates
} 
quality healthcare, telephony, internet access, energy reliability, and roads. It is on the scale of 0 (worst) to 1 (best) ${ }^{8}$.

Colonial origin is included in the test as an element of 'Dependency Theory' where developing countries and developed countries co-exist in a core-periphery system. This system indicates that developing countries are dependent on developed countries for their development (Ferraro 2008: 58-64). Given that the majority of the periphery and semi-periphery countries are colonized by the core countries, it is crucial to include colonial history as a determinant in economic development.

Additionally, the rhetoric is commonly accepted that colonial legacies have tremendous impacts on both colonized countries and the colonizers. Concurrently, ethnicity and religion also have a specific impact on domestic politics and state legitimacy. It is not difficult to find support for this claim. History has shown evidence from countries that specific groups of people claim statehood based on ethnicity and religion, for example, the Turkish in Turkey and the Jews in Israel. Ethnicity and religion are also the factors blamed for discrimination between different groups, for example, the Apartheid policy in South Africa, the current favored-Malay in Malaysia, or even the current criminal justice in particular and the political system in the United States in general.

Given the above discussion, I have included three variables: Colonial Origin, Ethnic Fractionalization, and Religious Fractionalization. History of Colonialization is recoded as a dummy variable where countries were either colonized or not. The former colonial ruler of the country excludes the British settler colonies (for example, United States and Australia), and exclusively focuses on 'Western overseas' colonialism. Each country that has been colonized

\footnotetext{
${ }^{8}$ See Appendix for full description of Public Service
} 
since 1700 is coded. In cases of several colonial powers, the last one is counted, if it lasted for ten years or longer ${ }^{9}$.

Ethnic Fractionalization is a combination of racial and linguistic characteristics, indicating how ethnically fractionalized is a state. The variable is on a scale of probability from 0 to $1^{10}$. Religion Fractionalization reflects the probability from 0 to 1 that two randomly selected people from a given country will not belong to the same religious group. The higher the number, the more fractionalized the society. ${ }^{11}$

Table 1.

Summary of Variables

Dependent Variable Independent Variables

\begin{tabular}{lll}
\hline State Legitimacy & GDP Growth Rate & Public Services \\
& Unemployment Rate & Ethnicity Fractionalization \\
Institutionalized Democracy & Religion Fractionalization \\
Political Rights & Colonial Origin \\
Civil Liberty & Property Rights \\
\hline
\end{tabular}

\section{Statistical Analysis}

On conducting the statistical analysis, I started by deciding which model should be deployed in this study. The Hausman test examines the null hypothesis that the preferred model is random effects versus the alternative of fixed effects. The result (p-value $=.000)$ indicates that the unique errors are not correlated with the regressors, thus, the null hypothesis is rejected, and fixed effects is favored (Torres-Reyna 2007). However, the fixed effects model cannot access the effect of time-invariant variables including colonial origin, ethnic fractionalization, and religion

\footnotetext{
${ }^{9}$ See Appendix for full description of Colonial Origin

${ }^{10}$ See Appendix for full description if Ethnic Fractionalization

${ }^{11}$ See Appendix for full description of Religion Fractionalization
} 
fractionalization. Thus, to resolve the problem, I have utilized the Mixed Effects Model (RabeHesketh \& Skrondal 2008: 127-8).

Model: Staleg $_{j k}=\alpha_{1}+\alpha_{2} v_{2 j k}+\alpha_{3} v_{3 j k}+\ldots+\alpha_{10} v_{10 j k}+\alpha_{11} v_{1 l j k}+\zeta_{j k}$ where $\alpha$ is the interceptions, $\mathrm{j}$ is year and k is country. Staleg is Level of State Legitimacy. Value of $\alpha_{2}$ is Institutionalized Democracy, $\alpha_{3}$ is Property Rights, $\alpha_{4}$ is Political Rights, and $\alpha_{5}$ is Civil Liberties, $\alpha_{6}$ is GDP Growth Rate, $\alpha_{7}$ is Unemployment Rate, $\alpha_{8}$ is Public Service, $\alpha_{9}$ is Colonial Origin, $\alpha_{10}$ is Ethnic Fractionalization, $\alpha_{11}$ is Religion Fractionalization. $\zeta_{\mathrm{jk}}$ is the residual. 


\section{CHAPTER V: ANALYSIS}

After running the test, the results are as follows.

Table 2 .

Mixed Effects Model of State Legitimacy on Democracy, Social Welfare and Economic

Development 2005-2017

\begin{tabular}{|c|c|}
\hline \multicolumn{2}{|l|}{ FIXED EFFECTS } \\
\hline Institutionalized Democracy & $\begin{array}{l}.044 * * \\
(.017)\end{array}$ \\
\hline Property Rights & $\begin{array}{l}.157 * * * \\
(.025)\end{array}$ \\
\hline Political Rights & $\begin{array}{l}.173 * * * \\
(.022)\end{array}$ \\
\hline Civil Liberties & $\begin{array}{l}.086 * * * \\
(.024)\end{array}$ \\
\hline GDP Growth Rate & $\begin{array}{l}.022 \\
(.055)\end{array}$ \\
\hline Unemployment Rate & $\begin{array}{l}-.093 * * * \\
(.023)\end{array}$ \\
\hline Public Service & $\begin{array}{l}.203 * * * \\
(.022)\end{array}$ \\
\hline Colonial Origin & $\begin{array}{l}-.052 * * \\
(.019)\end{array}$ \\
\hline Ethnic Fractionalization & $\begin{array}{l}-.086^{*} \\
(.036)\end{array}$ \\
\hline Religion Fractionalization & $\begin{array}{l}.009 \\
(.035)\end{array}$ \\
\hline \multicolumn{2}{|l|}{ RANDOM EFFECTS } \\
\hline Country level: Standard deviation & $\begin{array}{l}.098 * * * \\
(.008)\end{array}$ \\
\hline LogLikelihood & 2265.6157 \\
\hline $\begin{array}{l}\text { Countries }=159 \\
\mathrm{~N}=1,539 \\
* \mathrm{p}<.05 ; * * \mathrm{p}<.01 ; * * * \mathrm{p}<.001, \mathrm{tw} \\
\text { Standard Errors are in parentheses }\end{array}$ & \\
\hline
\end{tabular}

Table 2 presents the results from the model to test the combined effects of democratic, economic, and social welfare factors on state legitimacy. While more institutionalized 
democracy, improved factors of liberal democracy, and a higher quality of public service leads to a higher level of legitimacy, quality of public service is reportedly having the greatest impact on state legitimacy within a country. With a unit change in the quality of public service, state legitimacy changes by 20 percent in the same direction. It is at 4.4 percent for institutionalized democracy, approximately 16 percent for property rights, 17 percent for political rights and 8.6 percent for civil liberties, all in the same direction. Unemployment rates continues showing a negative relationship with the level of state legitimacy. For each unit change in unemployment rate, the state is less likely to be legitimate by approximately 9 percent.

The findings are consistent with the theories used in this study. First, the effect of democracy has been tested and shown to have a positive relationship with state legitimacy. The Theory of D-Principle is also validated by the consistent effect of institutionalized democracy, property rights, political rights and civil liberty on the level of state legitimacy. Second, the results of quality of public services and unemployment rates on state legitimacy help illustrate 'social contract' theory on the origin of the state. The findings, thus, strengthen the argument of state legitimacy and the quality of good and services it provides to the citizens.

In sum, the hypothesis: a state with better performance in macro issues, including economic performance, social welfare, and political participation, is more likely to enjoy a higher level of legitimacy, has been supported by the findings in the Mixed Effects Model. Keeping in control elements of ethnic diversity, religion fractionalization, and colonial origin, the findings show significance in the relationship between state legitimacy and state performance in fulfilling the social contract between the state and its people. The findings also emphasize the democratic aspects of the state, specifically in providing its citizens with access to property rights, political rights, and civil liberties, contributing to the process of institutionalizing 
democracy. A growing economy, as presented above, does not necessarily translate into a higher level of state legitimacy. Unemployment rate, on the other hand, contributes to the level of state legitimacy significantly.

Thus, the theories used in this study, Social Contract theory and Discourse Principle theory, are supported by the findings. Democracy is tested to be the critical element in generating higher level of political legitimacy. Public service and sustainable economic growth in terms of retaining a low unemployment rates and providing quality public service reflect role of the state in fulfilling its part in the social contract with the citizens in return for trust and recognition. It is, thus, expected that the state will have a higher level of legitimacy if it promotes democracy and quality goods and services. 


\section{CHAPTER VI: POLICY RECOMMENDATIONS, CONTRIBUTION AND FUTURE RESEARCH}

\section{Policy Recommendations}

Based on the findings, the study suggests that once being established, a state regardless of how it came into existence, should maintain its legitimacy. One of the mechanisms for maintaining this legitimacy is provision of a politically free environment, democratic institutions, and quality public service.

1. Recognizing the role of democracy is crucial. Granting political rights and civil liberty helps maintain the legitimacy of the state. Building democratic platforms to encourage citizen participation in politics is one mechanism. Ensuring that the rule of law is appropriately applied is another mechanism as it is shown throughout the tests that rule of law plays a positive role in promoting state legitimacy. To preserve the rule of law, it is essential to have an established democratic constitution, laws and regulations and a well-designed and impartial system of bureaucracy.

2. Public service should become the focus in state legitimacy. This study has shown that quality of public service plays a significant role in delivering state legitimacy. Thus, to maintain and retrieve legitimacy, a state should improve its ability to provide quality services including healthcare, education, transportation, and sanitation services.

3. As shown in the results, economic growth does not necessarily translate into state legitimacy. Unemployment rate, on the other hand, shows its consistent effect on the level of legitimacy. Increasing unemployment, specifically youth unemployment, 
leads to various detrimental social, economic and political consequences including an increasing criminal rate and social unrest (Azeng \& Yogo 2015) which challenge the state's legitimacy if it fails to assist the people in chaos. States, thus, should work on solving the question of how to limit and improve the unemployment rate. Indeed, the solution of economic growth partly answers the unemployment problem. A significant issue here, however, is how to sustainably build an economy in which a decrease in economic growth will not lead to a devastating increase in the unemployment rate.

\section{Contribution and Future Research}

This study contributes to the discussions on the role of legitimacy in the survival of a state. Failing states are often said to be the breeding land of instabilities and violence. As legitimacy contributes significantly to the survival of a state, understanding how a state can retrieve its legitimate status is crucial in preserving political stability. With the growing challenges from terrorism and nihilism to the legitimacy of the state, this study expects to contribute to policymaking as to how to confront these challenges. It is, indeed, concerned with security and stability, not only nationally but also at the regional and international levels.

Throughout the study, the history of colonialization has been considered as a determining factor of state legitimacy. It cannot be stressed enough to consider the role of colonial legacies in the existing world, especially in Third World and developing countries. Studying colonial legacies requires a comprehensive approach to examining their impacts socially, economically, and politically in former colonies. This study is a step towards addressing this aspect, explaining how colonial legacies may assert a significance impact on the statehood of a state. 
Religion, despite the discourse on its role in shaping state legitimacy, does not seem to have an impact on state legitimacy in this specific study. Within the scope of this study, the findings defeat the argument that religion plays a significant role in shaping legitimacy. Ethnic diversity, on the other hand, does play a role in determining the level of legitimacy. Therefore, future studies of identity politics in understanding its role in state legitimacy should be revisited. Additionally, to a certain extent, by demonstrating the positive relationship between state legitimacy and democracy, rejecting the impact of religion and downsizing the impact of ethnic diversity, the research strengthens the argument that the value of democracy is universal and should be embraced by all states to retrieve and maintain their legitimacy.

Quality of public service and elements of economic performance have significant impacts on the level of state legitimacy. However, in this research, quality of public service is treated as one variable; and there are only two economic indicators: GDP growth rates and unemployment rates. Future research can focus on examining which specific factors in public service and economic performance play a larger role in obtaining a higher level of state legitimacy.

Finally, on revisiting the definition of state legitimacy and its measurement in this study, there are two lessons to be taken seriously in future studies. On the one hand, the definition used in this study defines state legitimacy as "the extent that people regard the state as satisfactory and believe that no available alternative would be vastly superior" (OECD 2010). This definition suggests a normative but also measurable approach to state legitimacy. If the state satisfies citizens in aspects of democratic institutions, political rights, civil liberty, and provision of quality public service, it can be assumed that citizens will perceive their state as legitimate. On the other hand, state legitimacy measured in this study is the lack of corruption, quality of representativeness, government effectiveness, illicit economy, drug trade, protests and 
demonstrations, and power struggles. The definition used in the study and the measurement can be intuitively connected through democratic mechanisms. However, it is true that state legitimacy is a contested and normative definition. Future studies should focus on developing more theoretical justifications to clarify the use of respective theories and the measurement of state legitimacy to satisfy the normative elements of the definition. 


\section{CHAPTER VII: LIMITATIONS}

This study sets the unit of analysis to the state. Therefore, entities which are not recognized as a state within the international context have remained outside the purview of this study. This study excludes the external sources of legitimacy that are created by the international community in specific contexts (Israel, for example). It also overlooks cultural deviations in understanding state legitimacy. Additionally, no stateless or similar entities are included as this study concerns itself primarily with the state and its monopoly on violence. The study focuses on performance-based legitimacy instead of the historical origin of the state. However, the study acknowledges the obvious implications of history in forming political legitimacy, specifically the history of colonialization. Barbaric borders by the colonizers continue tearing apart communities and creating states where the people inside those states do not necessarily recognize the states' legitimacy (for example, different ethnic groups in Afghanistan).

Another limitation of this study is that it adopted a Western framework to examine legitimacy globally. The rationality approach and theory of democratization all have a Westernbias. There are concerns regarding the appropriateness of the framework to countries outside the Western world. Finally, this study lacks direct behavioral and normative responses from the population regarding state legitimacy. As the concept deals with citizens' satisfaction and obedience, measuring state legitimacy should come from a survey of the population for more accurate examination. 


\section{REFERENCES}

Ahl, B., \& Tieben, H. (2015). Modern Chinese Court Buildings, Regime Legitimacy, and the Public. International Journal for the Semiotics of Law, 28(3), 603-626.

http://doi.org/10.1007/s11196-015-9416-y

Andersen, M. S. (2012). Legitimacy in State-Building: A Review of the IR Literature. International Political Sociology, 6(2), 205-219. http://doi.org/10.1111/j.17495687.2012.00159.x

Aragon, J. (n.d.). Political Legitimacy. In Encyclopedia of Campaigns, Elections, and Electoral Behavior.

Azeng, T.F., \& Thierry, U.G. (2015). Youth unemployment, education and political instability: evidence from selected developing countries 1991-2009. Households in Conflict Network (HiCN) Working Paper 200. Brighton: The Institute of Development Studies.

Bernhard, M., Reenock, C., \& Nordstrom, T. (2004). The Legacy of Western Overseas Colonialism on Democratic Survival. International Studies Quarterly, 48(1), 225-250. http://doi.org/10.1111/j.0020-8833.2004.00298.x

Bernstein, M. (2005). Identity Politics. Annual Review of Sociology, 31, 47-74. Retrieved from http://www.jstor.org/stable/29737711

Bhat, N. (2004). Government Legitimacy Index. Center for Civil Society.

Birnbaum, S., Bodin, Ö., \& Sandström, A. (2015). Tracing the sources of legitimacy: the impact of deliberation in participatory natural resource management. Policy Sciences, 48(4), 443461. http://doi.org/10.1007/s11077-015-9230-0 
Blanton, R., David, T. M., \& Athow, B. (2001). Colonial style and Post Colonial Ethnic Conflict In Africa. Journal of Peace Research, 38(4), 475-476.

Bleaney, M., \& Dimico, A. (2016). State history, historical legitimacy, and modern ethnic diversity. European Journal of Political Economy, 43, 159-170. http://doi.org/10.1016/j.ejpoleco.2016.03.001

Bohman, J., \& Rehg, W. (2007). Jürgen Habermas. In Stanford Encyclopedia of philosophy. http://doi.org/10.1111/1467-9973.00225

Bonilia-Silva, E., \& Dietrich, D. (2011). The Sweet Enchantment of Color-Blind Racism in Obamerica. The Annals of the American Academy of Political and Social Science, 634, 190-206. Retrieved from http://www.jstor.org/stable/29779402

Brinkerhoff, D. W., Wetterberg, A., \& Dunn, S. (2012). Service Delivery and Legitimacy in Fragile and Conflict-Affected States. Public Management Review, 14(2), 273-293. http://doi.org/10.1080/14719037.2012.657958

Carol C. Gould (2010) Racism and Democracy Reconsidered, Social Identities, 6:4, 425-439, DOI: $10.1080 / 13504630020026396$

Caspersen, N. (2015). Degrees of legitimacy: Ensuring internal and external support in the absence of recognition. Geoforum, 66, 184-192. http://doi.org/10.1016/j.geoforum.2014.10.003

D’Aspremont, J. (2007). Legitimacy of Governments in the Age of Democracy. International Law and Politics, 38(877), 877-917.

Donovan, T., Denemark, D., \& Bowler, S. (2011). Trust in Government: The United States in Comparative Perspective. The Elements of Social Scientific Thinking. 
Ekeh, P. P. (1980). Colonialism and social structure [Inaugural lecture]. Ibadan University Press, June 5(June 1980), 1-22.

Fishman, R. (1990). Rethinking State and Regime: Southern Europe's Transition to Democracy. World Politics, 42(3), 422-440. doi:10.2307/2010418

Frickel, S., \& Davidson, D. J. (2004). Building Environmental States: Legitimacy and Rationalization in Sustainability Governance. International Sociology, 19(March 2004), 89110. http://doi.org/10.1177/0268580904040922

Ghazi-Tehrani, A. K., \& Pontell, H. N. (2015). Corporate crime and state legitimacy: the 2008 Chinese melamine milk scandal. Crime, Law and Social Change, 63(5), 247-267. http://doi.org/10.1007/s10611-015-9567-5

Gilley, B. (2006). The meaning and measure of state legitimacy: Results for 72 countries. International Political Science Review, 27(1), 47-71. http://doi.org/10.1111/j.14756765.2006.00307.x

Gilley, B. (2009). The Consequences of Legitimacy. In The Right to rule: How States win and lose legitimacy (pp. 140-206). Retrieved from http://www.web.pdx.edu/ gilleyb/RightToRule_Ch5.pdf

Gilley, B. (2012). State legitimacy: An updated dataset for 52 countries. European Journal of Political Research, 51(5), 693-699. http://doi.org/10.1111/j.1475-6765.2012.02059Gippert, B. J. (2016). The sum of its parts? Sources of local legitimacy. Cooperation and Conflict, 51(4), 522-538. http://doi.org/10.1177/0010836716652426

Grier, R. M. (1999). Colonial Legacies and Economic Growth. Public Choice, 98(3), 317-335. 
Habermas, J. (1996). Between facts and norms: Contributions to a discourse theory of law and democracy. Cambridge, Mass: MIT Press.

Hammond, Emily; Markell, L. D. (1976). Administrative Proxies for Judicial Review: Building Legitimacy From the Inside-Out. Harvard Environmental Law Review, 1, 313-364. http://doi.org/10.1525/sp.2007.54.1.23.

Harman, M., Martinez, J., Ponce, A., Pratt, C. S., Roberts, K., Steele, J., ... Randall, A. (2015). Open Government Index TM 2015 Report.

Hobbes, Thomas, Pogson Smith, W. G. (1909, 1952 printing) Hobbes's Leviathan. Oxford: Clarendon Press.

Ioris, A. A. R. (2015). Theorizing state-environment relationships. Progress in Human Geography, 39(2), 167-184. http://doi.org/10.1177/0309132513516893

Kaplanova, P. (2017). Essay on Legitimacy and Democracy. Challenges of the Future, 2(1), 1626.

Lange, M. K. (2004). British Colonial Legacies and Political Development. World Development, 32(6), 905-922. http://doi.org/10.1016/j.worlddev.2003.12.001

Larson, Allan L. (1980) Comparative political analysis /Chicago: Nelson-Hall, p.19.

Lawson, Stephanie. (1991). "Some Conceptual and Empirical Issues in the Study of Regime Change." Regime Change and Regime Maintenance in Asia and the Pacific. Canberra: Panther Publishing \& Printing, 1-28.

Locke, John, Abrams, Philip. (1967) Two Tracts on Government. London, Cambridge U.P.. 
Mamdani, M. (2001). Beyond Settler and Native as Political Identities: Overcoming the Political Legacy of Colonialism. Comparative Studies in Society and History, 43(4), 651-664. http://doi.org/10.2307/2696665

Marshall, M. G., \& Cole, B. R. (2014). Global Report 2014 State Fragility. Center for Systemic Peace. http://doi.org/10.1017/S1052703608000014

Martin F. J. Prachowny. (1993). Okun's Law: Theoretical Foundations and Revised Estimates. The Review of Economics and Statistics, 75(2), 331-336. doi:10.2307/2109440

Matsueda, R., \& Drakulich, K. (2009). Perceptions of Criminal Injustice, Symbolic Racism, and Racial Politics. The Annals of the American Academy of Political and Social Science, 623, 163-178. Retrieved from http://www.jstor.org/stable/40375894

Mcloughlin, C. (2014). State Legitimacy. http://doi.org/10.4324/9780203503805

Miller, E. (1971). David Easton's Political Theory. Political Science Reviewer, 7(1), 184-235. http://doi.org/10.1177/0951692895007001002

Ndayiragije, R., \& Stel, N. (2014). The Eye of the Beholder: Service Provision and State Legitimacy in Burundi. Africa Spectrum, 49(3), 3-28.

Nelson, D. (2002). Guest Introduction: Identity? Politics. Modern Language Studies, 32(1), 5-10. doi: $10.2307 / 3252050$

O'Donnell, P. (2006). Democratic Theory: A Basic Bibliography. The Good Society, 15(1), 6171. Retrieved from http://www.jstor.org/stable/20711240

OECD. (2010). The State's Legitimacy in Fragile Situations: Unpacking Complexity. Conflict and Fragility. http://doi.org/10.1787/9789264083882-en 
Okun, A.M. (1962). Potential GNP: it's measurement and significance. Proceedings of the Business and Economics Section of the American Statistical Association, 98-104.

Olsen, T. D. (2017). Political Stakeholder Theory: The State, Legitimacy, and the Ethics of Microfinance in Emerging Economies. Business Ethics Quarterly, 27(1), 71-98. http://doi.org/10.1017/beq.2016.59

Perroulaz, G., Fioroni, C., \& Carbonnier, G. (2010). International Development Policy | Revue internationale de politique de développement politique de développement : International Development Policy, 1, 149-169.

Pierre, J. (2011). Legitimacy by performance in democratic systems? Preparing for empirical analysis. In Nordisk Kommuneforskerkonferanse 2011 (pp. 24-25).

Podder, S. (2014). State building and the non-state: debating key dilemmas. Third World Quarterly, 35(February 2015), 1615-1635. http://doi.org/10.1080/01436597.2014.970864

Rousseau, Jean-Jacques. (1950) The Social Contract and Discourses. New York: Dutton.

Scholz, L. H. (2016). Privacy Petitions and Institutional Legitimacy.

Seifter, M. (2014). States, Agencies, and Legitimacy. Vanderbilt Law Review, 67(2), 443-504. http://doi.org/10.1525/sp.2007.54.1.23.

Sil, R., \& Chen, C. (2004). State legitimacy and the (In)significance of democracy in postcommunist Russia. Europe - Asia Studies, 56(3), 347-368. http://doi.org/10.1080/09668130410001682672

Sobek, D., \& Thies, C. G. (2015). Civil Wars and Contemporary State Building: Rebellion, Conflict Duration, and Lootable Resources. Civil Wars, 17(1), 51-69. http://doi.org/10.1080/13698249.2015.1059568 
Rabe-Hesketh, Sophia \& Skrondal, Anders. (2008). Multilevel and Longitudinal Modeling Using Stata, Second Edition (3rd ed.). Stata Press, 127-8.

Tebble, A. (2006). Exclusion for Democracy. Political Theory,34 (4), 463-487. Retrieved from http://www.jstor.org/stable/20452475

Todorov, T., \& Maxwell, M. (1990). Racism. Salmagundi, (88/89), 47-53. Retrieved from http://www.jstor.org/stable/40548461

Torres-Reyna, O. (2007). Panel data analysis fixed and random effects using Stata (v. 4.2). Data \& Statistical Services, Priceton University.

Vincent Ferraro, "Dependency Theory: An Introduction," in The Development Economics Reader, ed. Giorgio Secondi (London: Routledge, 2008), pp. 58-64

Warren, M. (1994). Democracy and Difference. The Newsletter of PEGS, 4(2), 1-7. Retrieved from http://www.jstor.org/stable/20710651

Wesley, M. (2008). The State of the Art on the Art of State Building. Global Governance, 1(14), 369-385. 


\section{APPENDIX: DESCRIPTION OF VARIABLES IN PRIMARY DATASET}

All variables in this study have been recoded to the scale 0 (lowest/worst) to 1 (highest/best) from the primary dataset in this study.

The study uses data from the dataset compiled by Jan Teorell, Stefan Dahlberg, Sören Holmberg, Bo Rothstein, Anna Khomenko, and Richard Svensson at the University of Gothenburg, Sweden. It consists of approximately 2500 variables from more than 100 data sources. In the Quality of Government Standard Cross-sector dataset, data from and around 2013 are included. Data from 2013 are prioritized; however, if no data are available for a country for 2013, data from 2014 are included. If no data exist for 2014, data from 2012 are included, and so on up to a maximum of $+/$ - three years. The unit of analysis is state (Teorell et al. 2013: 5). Based on data availability, a pooled cross-sectional and time-series research design will be adopted to examine the data collected for 196 countries from 1946 to 2017.

Civil Liberties measure civil liberties allow for the freedoms of expression and belief, associational and organizational rights, the rule of law, and personal autonomy without interference from the state. The more specific list of rights considered varies over the years. Countries are ranked between 1 (most free) and 7 (least free).

Colonial Origin is a tenfold classification of the former colonial ruler of the country excluding the British settler colonies (the US, Canada, Australia, Israel and New Zealand), and exclusively focusing on "Western overseas" colonialism. This implies that only Western colonizers (e.g., excluding Japanese colonialism), and only countries located in the non-Western hemisphere "overseas" (e.g., excluding Ireland \& Malta), have been coded. Each country that has been colonized since 1700 is coded. In cases of several colonial powers, the last one is counted, if it lasted for ten years or longer. 
Ethnic Fractionalization involves a combination of racial and linguistic characteristics, indicating how ethnically fractioned is a state. The variable is on a scale from 0 to 1.

GDP growth rates is the percentage that the economy has grown in a given time within a country's boundary (Teorell et al. 2013: 642).

Institutionalized Democracy is an additive eleven-point scale (0-10). The operational indicator of democracy is derived from coding the competitiveness of political participation, the openness and competitiveness of executive recruitment, and constraints on the chief executive.

Political Rights measures political rights that enable people to participate freely in the political process, including the right to vote freely for distinct alternatives in legitimate elections, compete for public office, join political parties and organizations, and elect representatives who have a decisive impact on public policies and are accountable to the electorate. The specific list of rights considered varies over the years. Countries are ranked between 1 (most free) to 7 (least free).

Property Rights scores the degree to which a country's laws protect private property rights and the degree to which its government enforces those laws. It also accounts for the possibility that private property will be expropriated. Besides, it analyzes the independence of the judiciary, the existence of corruption within the judiciary, and the ability of individuals and businesses to enforce contracts. The less certain the legal protection of property is and the greater the chances of government expropriation of property are, the higher a country's score is. The country's property rights score ranges from 0 and 100, where 100 represents the maximum degree of protection of property rights.

Public Service measures the provision of health, education, and sanitation services, among others, are critical roles of the state. Includes pressures and measures related to policing, 
criminality, education provision, literacy, water and sanitation, infrastructure, quality healthcare, telephony, internet access, energy reliability, roads. It is on the scale of 1 (best) to 10 (worst).

Religion Fractionalization reflects the probability that two randomly selected people from a given country will not belong to the same religious group. The higher the number, the more fractionalized the society. It is on a scale from 0 to 1 .

State Legitimacy indicates corruption and lack of representativeness in the government. It includes pressures and measures related to corruption, government effectiveness, political participation, electoral processes, levels of democracy, illicit economy, drug trade, protests and demonstrations, and power struggles (Teorell et al. 2013: 283). The variable of State Legitimacy is on a scale from 0 to 10 with 0 representing the highest legitimacy and 10 representing the lowest legitimacy.

Tax revenue (\% of GDP) refers to compulsory transfers to the central government for public purposes. Certain compulsory transfers such as fines, penalties, and most social security contributions are excluded. Refunds and corrections of erroneously collected tax revenue are treated as negative revenue.

Unemployment Rate (\%) refers to the share of the labor force that is without work but available for and seeking employment (\% total labor force) 